\title{
A COMPARATIVE STUDY OF VISUAL OUTCOME AND COMPLICATIONS OF IN-THE-BAG INTRAOCULAR LENS AND IN-THE-SULCUS INTRAOCULAR LENS
}

\author{
Rasikpriya Sandhuํ, Daya Chand Gupta ${ }^{2}$
}

${ }^{1}$ Resident, Department of Ophthalmology, Mahatma Gandhi Medical College \& Hospital, Jaipur. 2Professor, Department of Ophthalmology, Mahatma Gandhi Medical College \& Hospital, Jaipur.

\section{ABSTRACT}

\section{BACKGROUND}

The aim of this study is to compare the effect of site of implantation of posterior chamber intra-ocular lens (PC IOL), i.e., in-the-bag IOL and in-the-sulcus IOL on the basis of visual outcome and complications.

\section{MATERIALS AND METHODS}

This was a prospective comparative study of 100 patients who underwent SICS with IOL implantation. Patients were randomised by chit box method and divided into 2 groups according to placement of IOL, i.e., Group A (IOL In-the-bag) and Group B (IOL In-thesulcus). Post-operative examination of the patients was done on 1st day, 7th day, 1st month, 3rd month and 6th months with regard to Visual acuity, Anterior segment evaluation on slit lamp and Posterior segment examination.

\section{RESULTS}

In both groups, majority of patients were in the age group of 50-60 years. The male female ratio was 54:46 in both groups. Preoperatively, in Group A, 76\% patients had vision 6/24-6/60. Whereas, in Group B, 56\% patients had vision 6/24-6/60. In Group A, at 6 months followup, 76\% patients had best corrected visual acuity (BCVA) 6/6. No patients had flare, 20\% had pigments and 96\% had no corneal oedema. In Group B, at 6 months followup, 56\% patients had BCVA 6/6. None of the patients had flare, 36\% had pigments and $98 \%$ had no corneal oedema. However, $2 \%$ patients had moderate corneal oedema.

\section{CONCLUSION}

The current study shows that a higher number of patients achieved a BCVA of 6/6 with in-the-bag IOL. The incidence of postoperative complications is more with in-the-sulcus IOL implantation as compared to in-the-bag IOL.

\section{KEYWORDS}

Small Incision Cataract Surgery, In-the-bag, In-the-sulcus.

HOW TO CITE THIS ARTICLE: Sandhu R, Gupta DC. A comparative study of visual outcome and complications of in-the-bag intraocular lens and in-the-sulcus intraocular lens. J. Evolution Med. Dent. Sci. 2017;6(28):2292-2295, DOI: $10.14260 /$ Jemds/2017/493

\section{BACKGROUND}

Charles Kelman introduced the world to small incision cataract surgery. 1

The first innovative idea to advance the safety of phacoemulsification was to develop a new technique of capsulotomy. The technique of continuous curvilinear capsulorhexis (CCC) allows placement of IOL in the natural anatomical position. ${ }^{2}$ This technique produces a strong capsular rim that resists tearing even when stretched during lens material removal or lens implantation.

Early results of posterior chamber intraocular lens (PC IOL) implantation in the ciliary sulcus appeared better in comparison to iris supported and anterior chamber (AC) lenses. However, the long-term followup complications began to appear mainly because of contact between the posterior surface of the iris and the ciliary body, e.g., corneal

Financial or Other, Competing Interest: None.

Submission 15-03-2017, Peer Review 28-03-2017,

Acceptance 30-03-2017, Published 06-04-2017.

Corresponding Author:

Dr. Rasikpriya Sandhu,

22, Shivaji Marg,

Near Diggi House,

C-Scheme,

Jaipur-302004.

E-mail: rasikpriya@gmail.com

DOI: $10.14260 /$ jemds $/ 2017 / 493$ oedema, pupillary capture, decentration, iris chaffing, posterior synechiae and posterior capsular opacification (PCO). ${ }^{3}$

However, in beginner's hand during surgical complications like positive vitreous pressure or posterior capsule rent (PCR), IOL can be easily implanted in-the-sulcus.

\section{Aims and Objectives}

To compare the post-operative visual outcome and complications after SICS surgery between the two groups-

A) IOL in-the-bag.

B) IOL in-the-sulcus.

\section{MATERIALS AND METHODS}

This study was conducted at Department of Ophthalmology, Mahatma Gandhi Medical College and Hospital, Jaipur. It is an observational comparative prospective study on 100 eyes of 100 patients aged 50 years or above with senile cataract who underwent manual small incision cataract surgery (SICS) with Intra-ocular lens (IOL) implantation.

Inclusion Criteria were patients undergoing manual SICS with a PC IOL implantation, age group between 50 to 70 years and patients with senile cataract up to Grade 3 nuclear sclerosis.

Exclusion criteria were hard brown cataract, cataracts other than senile cataract, patients with intraoperative and 
post-operative complications, systemic diseases and corneal pathology.

Patients were randomly divided in to 2 groups by chit box method (simple randomisation) according to placement of IOL, ie, Group A: IOL In-the-bag and Group B: IOL In-thesulcus. Post-operative examination of the patients was done on 1st day, 7th day, 1st month, 3rd month and 6th months with regard to Visual acuity, Anterior segment evaluation on slit lamp and Posterior segment examination.

Statistical analysis was performed using SPSS software (version 23.0). Difference between the two groups were evaluated using chi-squared test.

\section{RESULTS}

In both groups, majority of patients were in the age group of 50-60 years. The male female ratio was 54:46 in both groups.
Pre-operatively, in Group A, 76\% patients had vision 6/246/60; whereas, in Group B, 56\% patients had vision 6/246/60 (Table 1). In Group A, at 6 months followup, 76\% patients had best corrected visual acuity (BCVA) 6/6 (Table 2). No patients had flare (Table 3), $20 \%$ had pigments (Table 4) and $96 \%$ had no corneal oedema (Table 5). In Group B, at 6 months followup, $56 \%$ patients had BCVA 6/6 (Table 2). None of the patients had flare (Table 3), $36 \%$ had pigments (Table 4) and 98\% had no corneal oedema (Table 5). However, 2\% patients had moderate corneal oedema (Table 5).

At 6 months followup, for vision $6 / 6$ chi-square value was 1.471 and $p$ value is 0.0348 (Significant).

\begin{tabular}{|c|c|c|c|c|c|c|c|c|}
\hline & \multicolumn{2}{|c|}{ Group A } & \multicolumn{2}{|c|}{ Group B } & \multicolumn{2}{|c|}{ Total } & \multirow{2}{*}{$\begin{array}{c}\text { Chi Square } \\
\text { Value }\end{array}$} & \multirow{2}{*}{ P-Value } \\
\hline & Number & $\%$ & Number & $\%$ & Number & $\%$ & & \\
\hline $6 / 9$ & 2 & 4 & 2 & 4 & 4 & 4 & \multirow{7}{*}{0.7059} & \multirow{7}{*}{0.4008} \\
\hline $6 / 12$ & 3 & 6 & 4 & 8 & 7 & 7 & & \\
\hline $6 / 18$ & 1 & 2 & 3 & 6 & 4 & 4 & & \\
\hline $6 / 24$ & 11 & 22 & 4 & 8 & 15 & 15 & & \\
\hline $6 / 36$ & 14 & 28 & 6 & 12 & 20 & 20 & & \\
\hline $6 / 60$ & 13 & 26 & 18 & 36 & 31 & 31 & & \\
\hline$<6 / 60$ & 6 & 12 & 13 & 26 & 19 & 19 & & \\
\hline Total & 50 & 100 & 50 & 100 & 100 & 100 & & \\
\hline
\end{tabular}

\begin{tabular}{|c|c|c|c|c|c|c|c|c|}
\hline & \multicolumn{2}{|c|}{ Group A } & \multicolumn{2}{|c|}{ Group B } & \multicolumn{2}{|c|}{ Total } & \multirow{2}{*}{$\begin{array}{c}\text { Chi Square } \\
\text { Value }\end{array}$} & \multirow{2}{*}{ P-Value } \\
\hline & Number & $\%$ & Number & $\%$ & Number & $\%$ & & \\
\hline $6 / 6$ & 38 & 76 & 28 & 56 & 66 & 66 & 1.471 & 0.0348 \\
\hline $6 / 9$ & 8 & 16 & 14 & 28 & 22 & 22 & 0.231 & 0.1475 \\
\hline $6 / 12$ & 1 & 2 & 5 & 10 & 6 & 6 & 0.085 & 0.0921 \\
\hline $6 / 18$ & 1 & 2 & 1 & 2 & 2 & 2 & \multirow{5}{*}{1.0000} & \multirow{5}{*}{1.0000} \\
\hline $6 / 24$ & 1 & 2 & 1 & 2 & 2 & 2 & & \\
\hline $6 / 36$ & 0 & 0 & 0 & 0 & 0 & 0 & & \\
\hline $6 / 60$ & 1 & 2 & 1 & 2 & 2 & 2 & & \\
\hline$<6 / 60$ & 0 & 0 & 0 & 0 & 0 & 0 & & \\
\hline Total & 50 & 100 & 50 & 100 & 100 & 100 & & \\
\hline
\end{tabular}

\begin{tabular}{|c|c|c|c|c|c|}
\hline Group A & POD 1 & POD 7 & POM 1 & POM 3 & POM 6 \\
\hline 0 & 41 & 44 & 48 & 50 & 50 \\
\hline+1 & 5 & 4 & 2 & 0 & 0 \\
\hline+2 & 4 & 2 & 0 & 0 & 0 \\
\hline+3 & 0 & 0 & 0 & 0 & 0 \\
\hline+4 & 0 & 0 & 0 & 0 & 0 \\
\hline \multicolumn{6}{|l|}{ Group B } \\
\hline 0 & 21 & 44 & 48 & 50 & 50 \\
\hline+1 & 21 & 5 & 2 & 0 & 0 \\
\hline+2 & 4 & 1 & 0 & 0 & 0 \\
\hline+3 & 4 & 0 & 0 & 0 & 0 \\
\hline+4 & 0 & 0 & 0 & 0 & 0 \\
\hline p-Value & 0.0000 & 1.0000 & 1.0000 & 1.0000 & 1.0000 \\
\hline \multicolumn{6}{|c|}{ Table 3. Distribution of Cases According to Post-Operative Pigments } \\
\hline
\end{tabular}

POD = Post-operative day.

POM = Post-operative Month. 


\begin{tabular}{|c|c|c|c|c|c|}
\hline Group A & POD 1 & POD 7 & POM 1 & POM 3 & POM 6 \\
\hline Present & 26 & 27 & 21 & 15 & 10 \\
\hline Absent & 24 & 23 & 29 & 35 & 40 \\
\hline Group B & & 18 & 18 & 18 & 18 \\
\hline Present & 40 & 32 & 32 & 32 & 32 \\
\hline Absent & 10 & 0.0704 & 0.5385 & 0.5235 & 0.0748 \\
\hline p-Value & 0.0031 & Table 4. Distribution of Cases According to Post-Operative Pigments \\
\hline \multicolumn{7}{r}{}
\end{tabular}

POD = Post-operative day.

$\mathrm{POM}=$ Post-operative month.

\begin{tabular}{|c|c|c|c|c|c|}
\hline Group A & POD 1 & POD 7 & POM 1 & POM 3 & POM 6 \\
\hline Nil & 40 & 44 & 48 & 48 & 48 \\
\hline Mild & 6 & 4 & 1 & 1 & 1 \\
\hline Moderate & 3 & 2 & 1 & 1 & 1 \\
\hline Severe & 1 & 0 & 0 & 0 & 0 \\
\hline \multicolumn{6}{|l|}{ Group B } \\
\hline Nil & 23 & 30 & 37 & 46 & 49 \\
\hline Mild & 19 & 16 & 13 & 3 & 0 \\
\hline Moderate & 5 & 4 & 0 & 1 & 1 \\
\hline Severe & 3 & 0 & 0 & 0 & 0 \\
\hline p-Value & 0.0004 & 0.0014 & 0.0021 & 0.3997 & 0.5577 \\
\hline
\end{tabular}

POD = Post-operative Day .

$\mathrm{POM}=$ Post-operative Month.

\section{DISCUSSION}

Ciliary sulcus is the space between the posterior surface of the base of the iris and the anterior surface of the ciliary body. ${ }^{4}$ Both the ciliary sulcus and the capsular bag are possible sites for implantation of a lens implant following a cataract surgery.

Post-operative transient corneal oedema depends on various factors such as previous corneal pathology, age, underlying systemic disease, and surgical trauma. 5,6,7

Pigment dispersion syndrome (PDS) occurs when iris pigmentary epithelium pigment deposits pass through the aqueous humour and are dispersed throughout the anterior segment.

Pigment dispersion syndrome secondary to intraocular lens (IOL) implantation in-the-sulcus can be a potential problem. ${ }^{8}$ Rubbing between the IOL optic and iris seems to contribute to the high flare counts in eyes with a sulcus-tosulcus IOL fixation. ${ }^{9}$

Our study is comparable with Jayashree et al (2012) ${ }^{3}$ who found that $78 \%$ patients had BCVA of $6 / 6$ and overall BCVA of more than $6 / 9$ was seen in $90 \%$ of patients with in-the-sulcus IOL. They also found that $18 \%$ patients had pigment dispersion with in-the-bag IOL and 32\% patients had pigment dispersion with in-the-sulcus IOL. ${ }^{3}$

D J Apple et al (1985) ${ }^{10}$ compared indications, advantages and disadvantages of ciliary sulcus and capsular fixation of PC IOL. They suggested that whenever possible the loops off the PC IOL should be implanted within the bag. The position of the lens optic and the loops in the natural anatomical position isolated from the highly vascular uveal tissue and the blood aqueous barrier. They also found that this might minimise the potential of complications that were associated with the irisciliary body contact.
All the above-mentioned factors influence the final postoperative VA and the account for the associated complications of in-the-sulcus IOL.

\section{CONCLUSION}

The current study shows that a higher number of patients achieved a BCVA of $6 / 6$ with in-the-bag IOL. The incidence of post-operative complications is more with in-the-sulcus IOL implantation as compared to in-the-bag IOL.

\section{REFERENCES}

[1] Kelman CD. Phaco-emulsification and aspiration. A new technique of cataract removal. A preliminary report. Am J Ophthalmol 1967;64(1):23-35.

[2] Gimbel HV, Neuhann T. Development, advantages, and methods of the continuous circular capsulorhexis technique. J Cataract Refract Surg 1990;16(1):31-7.

[3] Jayshree MP, Dasara LV. Comparative study of postoperative vision and complications with sulcus fixated IOL and in-the-bag IOL. JPMBS 2012;14(14):1-6.

[4] Schnaudigel OE. Anatomy of the ciliary sulcus. Fortschr Ophthalmol 1990;87(4):388-9.

[5] Setala K. Corneal endothelial cell density in iridocyclitis. Acta Ophthalmol (Copenh) 1979;57(2):277-86.

[6] Weston BC, Bourne WM, Polse KA, et al. Corneal hydration control in diabetes mellitus. Invest Ophthalmol Vis Sci 1995;36(3):586-95.

[7] O'Neal MR, Polse KA. Decreased endothelial pump function with aging. Invest Ophthalmol Vis Sci 1986;27(4):457-63. 


\section{Jemds.com}

[8] Brandt JD, Mockovak ME, Chayet A. Pigmentary dispersion syndrome induced by a posterior chamber phakic refractive lens. Am J Ophthalmol 2001;131(2):260-3.

[9] Amino K, Yamakawa R. Long-term results of out-ofthe-bag intraocular lens implantation. J Cataract Refract Surg 2000;26(2):266-70.
Original Research Article

[10] Apple DJ, Reidy JJ, Googe JM, et al. A comparison of ciliary sulcus and capsular bag fixation of posterior chamber intraocular lenses. J Am Intraocul Implant Soc 1985;11(1):44-63. 